https://helda.helsinki.fi

Facial and verbal expressions in assessing stories and topics

Ruusuvuori, Johanna

2009

Ruusuvuori , J \& Peräkylä , A 2009 , ' Facial and verbal expressions in assessing stories and topics ', Research on Language and Social Interaction, vol. 42 , no. 4 , pp. 377-394.

http://hdl.handle.net/10138/29481

publishedVersion

Downloaded from Helda, University of Helsinki institutional repository.

This is an electronic reprint of the original article.

This reprint may differ from the original in pagination and typographic detail.

Please cite the original version. 
This article was downloaded by: [University of Helsinki]

On: 3 January 2011

Access details: Access Details: [subscription number 917206032]

Publisher Routledge

Informa Ltd Registered in England and Wales Registered Number: 1072954 Registered office: Mortimer House, 3741 Mortimer Street, London W1T 3JH, UK

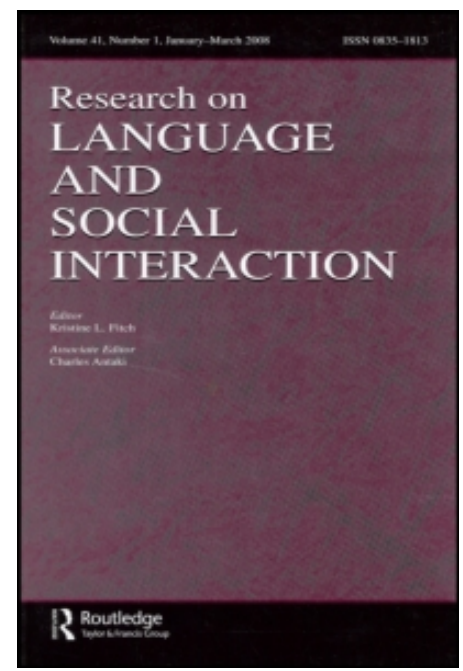

\section{Research on Language \& Social Interaction}

Publication details, including instructions for authors and subscription information:

http://www.informaworld.com/smpp/title content=t775653697

\section{Facial and Verbal Expressions in Assessing Stories and Topics}

Johanna Ruusuvuoria; Anssi Peräkyläb

${ }^{a}$ Department of Social Research, University of Tampere, Finland ${ }^{b}$ Helsinki Collegium for Advanced

Studies, University of Helsinki, Finland

Online publication date: 20 November 2009

To cite this Article Ruusuvuori, Johanna and Peräkylä, Anssi(2009) 'Facial and Verbal Expressions in Assessing Stories and Topics', Research on Language \& Social Interaction, 42: 4, 377 - 394

To link to this Article: DOI: $10.1080 / 08351810903296499$

URL: http://dx.doi.org/10.1080/08351810903296499

\section{PLEASE SCROLL DOWN FOR ARTICLE}

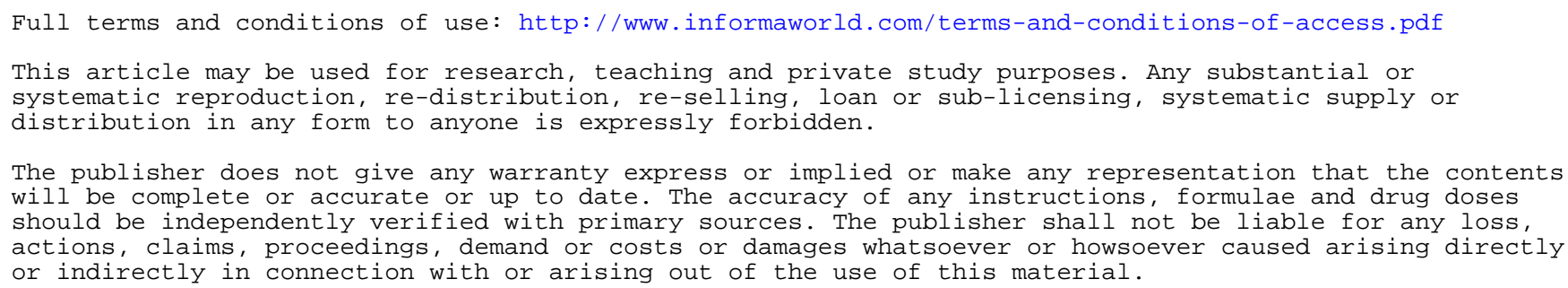




\title{
Facial and Verbal Expressions in Assessing Stories and Topics
}

\author{
Johanna Ruusuvuori \\ Department of Social Research \\ University of Tampere, Finland \\ Anssi Peräkylä \\ Helsinki Collegium for Advanced Studies \\ University of Helsinki, Finland
}

\begin{abstract}
This article examines the intertwining of facial and verbal expressions in assessing stories and topics. The main focus is on the facial expressions of the speaker of a story or telling that occur before their verbal evaluation. It is shown how speakers and recipients arrange face and talk in different configurations in order to display their stance toward what is being told. A key finding is that facial expression can stretch the temporal boundaries of an action. This temporal flexibility of the face enforces its role as a subtle device for securing shared understanding and affiliation. The data consist of 10 telling sequences that are closed up with assessments, drawn from Finnish two-party everyday conversations.
\end{abstract}

Assessments are a common way to receive and appreciate stories and other kinds of telling, such as announcements and observations in conversation (e.g., Jefferson, 1978; Kjaerbeck \& Assmuss, 2005; Ochs \& Capps, 2001; Schegloff, 1997). The delivery and reception of stories and other tellings involve various linguistic and nonlinguistic resources. Already in the 1980s Charles and Marjorie Harness Goodwin $(1987,1992)$ demonstrated how assessments often entail multimodal expression: not only words but gesture and gaze alike. Since then, the interplay of gesture and/or gaze in the coconstruction of storytelling has been examined by, e.g., Heath (1986), the Goodwins (C. Goodwin \& Goodwin, 2000; M. H. Goodwin, 1980), and Stivers (2008). Stivers found that visible response tokens (such as nods) and vocal continuers (such as "mm-hm") respond to different elements of the telling and are attentive to separate aspects of the ongoing social interaction: While vocal continuers confirm alignment with the activity of storytelling, nods show affiliation with the teller's stance toward the telling. In this article we will concentrate on a mode of visible communication that has gained less attention in previous literature on assessments and storytelling: the role of facial expression in assessing stories and topics. We will describe how the participants' facial expression intertwines with vocal assessments in

We would like to thank Anna Lindström, Lorenza Mondada, and two reviewers for their very helpful and insightful comments. The study has been made possible by two research grants from the Academy of Finland: Language and Social Action: A Comparative Study of Affiliation and Disaffiliation across National Communities and Institutional Contexts, and Emotion, Interaction and Institutions.

Correspondence should be sent to Johanna Ruusuvuori, Department of Social Research, University of Tampere, Kalevantie 5, 33014 Tampere, Finland. E-mail: johanna.ruusuvuori@uta.fi 
coconstructing affiliating stances toward the telling in focus, and argue that facial expression has a significant role in confirming affiliation in this context.

\section{EARLIER RESEARCH ON FACIAL EXPRESSION AND ASSESSMENTS}

There are two major streams of contemporary empirical research on facial expression. One focuses on individuals rather than interactions, and is strongly associated with the work of Paul Ekman. As early as the 1960s he had started a cross-cultural study on facial expression of emotion (e.g., Ekman, Sorenson, \& Friessen, 1969). Using photos and films of faces with different expressions, Ekman and his colleagues tried to pin down the connections between emotional states and details of the muscular movement in the face, as well as the ways in which people recognize such movements as expressions of particular emotions (for an accessible overview, see Ekman, 2003; see also Izard, 1971). Although Ekman discusses the uses of facial expression in social interaction (1979), the main focus of his work lies elsewhere, that is, in the ways in which internal emotional states are expressed and recognized in and through the face.

A rather different take on facial expression can be found in the work of Chovil $(1991,1997)$, Bavelas (Bavelas \& Chovil, 1997, 2000) and Fridlund (1996). Rather than focusing on the functions of the face as an output of internal emotional processes, they examine facial expressions as "visible acts of meaning" (Bavelas \& Chovil, 2000), by considering the ways in which facial displays "are part of the integrated message with words" (p. 166). Using video recorded data from two-party conversations in a psychology laboratory setting, Chovil (1991) found two major types of facial displays. Syntactic displays involve facial expressions (most often, raising or lowering eyebrows) that serve, for example, to emphasize or underline what is said, to mark a question, or the beginning or the continuation (after a sidetrack) of a story. In semantic displays, the facial expression, for example, conveys the personal reaction of the speaker to what is spoken about, or it can involve reenactment of past experiences, or it can signal thinking or remembering. Our project is informed by Bavelas and Chovil's in that we investigate facial expression as a communicative resource rather than as an indication of internal psychophysical states. However, unlike Bavelas and Chovil, we will not primarily focus on the ways in which facial expression signals a particular meaning (an emphasis or a stance) in the context of an utterance. In our conversation analytical approach, the primary focus is on the interplay of the facial and other expressions taking place in interaction, as we examine the moment-by-moment unfolding of assessment sequences in storytelling. Similar to participants' vocal contributions, their facial expressions interact with each other on a momentary basis and in concert with other modalities, forming a context that guides the choice of the next turn in interaction.

Within the conversation analytic framework, facial expression has not been systematically studied before us. However, a theoretical framework outlining the possibility of such study was provided in 1980 in M. H. Goodwin's study of processes of mutual monitoring in conversation. She pointed out that the participants' visual access to each other's bodies has important consequences for the organization of interaction:

... the speaker might produce not only paralinguistic but also kinesic displays about how his or her talk is to be understood and interpreted. For their part, the recipients might not only attend to such 
actions of the speaker but also produce nonvocal displays of their own that provide their understanding of the speaker's talk. (...) The speaker, being able to see such displays, might take them into account in the production of talk. (M. H. Goodwin, 1980, p. 303)

Goodwin focused her study on gestures such as nods, head shakes, and changes in body posture. However, she pointed out that "other nonvocal actions such as eyebrow flashes, smiles, eyeball rolls, jerks of the head indicating 'take' and so forth" (M. H. Goodwin, 1980, p. 309) are also used to convey the recipients' (and the speakers', we might add) understandings and stance.

In C. Goodwin and Goodwin's article (1987) on assessments in storytelling, they used assessments as an interactional environment for the analysis of the organization of a range of social, cognitive, and linguistic phenomena in conversation, including the building of congruent understanding on the topic talked about, and they discussed a range of different modalities in achieving this. In this article we study assessments from this point of view, paying specific attention to the role of facial expression in this activity. By "face" or "facial expression" we refer to observable changes in the gestalt of face in relation to the previous one, such as frowns and smiles. Following the line of research originally suggested by M. H. Goodwin (1980), we examine the ways in which facial expression is involved in eliciting as well as producing the desired reception of the story or other kind of telling. We will concentrate on assessments that occur either at the closure of storytelling or in response to other kinds of tellings.

\section{METHOD}

Our data consist of Finnish two-party everyday conversations. A somewhat constrained environment was needed to secure the technical quality of recordings necessary for the analysis of facial expression. We invited dyads of students (who were friends or acquaintances) to have a free lunch while their interaction was recorded with three video cameras. The lunches took place in a room adjacent to a student refectory. Figure 1 shows the seating arrangement

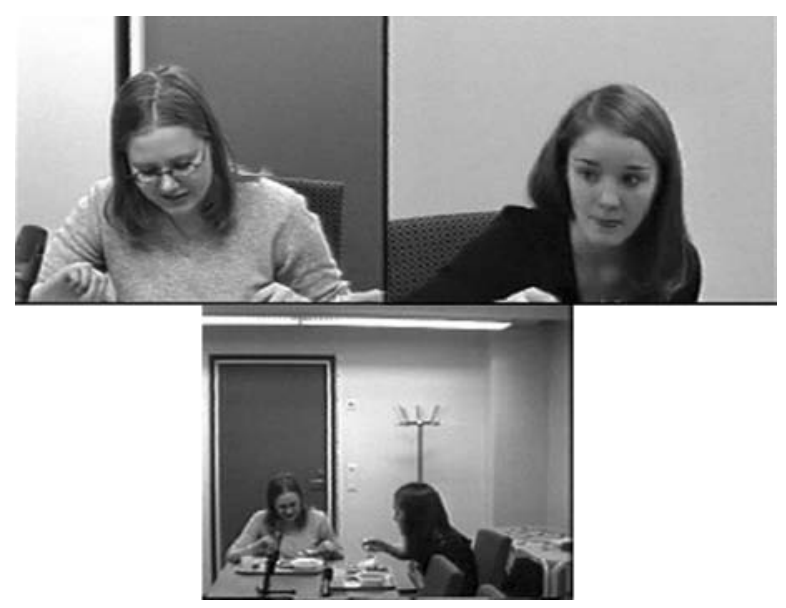

FIGURE 1 Seating arrangement. 
Out of five half-hour lunch conversations (with five different dyads, all female) we have extracted 114 assessment sequences from different sequential environments. Our preliminary analysis suggested that facial expressions can emphasize or modify the valence of the lexical assessment as well as secure the mutual alignment of the parties. We called these two functions semantic and relational (see Peräkylä \& Ruusuvuori, 2006; cf. Chovil, 1991).

Since these general observations we have continued our analysis in a more restricted sequential environment by focusing on assessments at the closure of storytellings or accompanying other kind of tellings, and the face work that goes on during the telling as well as the evaluation. For the present study we have analyzed thoroughly 10 telling sequences that are closed up with assessments. Out of these 10 sequences, 6 involve storytelling and 4 other kinds of telling.

We will show that speakers and recipients can arrange face and talk in different configurations in order to display their stance toward what is being told. We have organized the presentation of the results of the analysis in a way that proceeds from the most straightforward cases toward the more complex ones. We will first consider the positioning of facial expression with regard to the onset and closure of the telling, and show three cases that illustrate three different locations of facial expression in relation to this. In the first one (Extract 1), facial expression foreshadows the lexical elements that encode the stance of the speaker, in the second one (Extract 2), facial expression (embodying the speaker's stance) accompanies the verbal expression that introduces an object to be assessed by the recipient, and in the third one (Extract 3), facial expression immediately follows the lexical encoding of the speaker's stance. Through these examples we describe how facial expression can extend the boundaries of the spoken turn of talk (and thus work in service of the relational task in securing congruent understanding). Thereafter, in Extracts 4 and 5, we will focus more thoroughly on showing how facial expression of the storyteller is treated by the recipients as making relevant a reciprocation of the stance that is embedded in the telling.

\section{FACIAL EXPRESSION FORESHADOWING THE TELLING}

Consider Extract 1, a story about bugs that will not disappear from the sewer of A's kitchen. The story is a second story that follows the first one, told by B, about bugs in her sewer. Lines 1-5 are related to the first story, and the new one starts in line 9. A is on the left and B on the right in the framegrabs. The double slash mark in the transcript marks the place from where the framegrab is taken.

Extract 1 (see Figures 2 and 3 for accompanying frames)

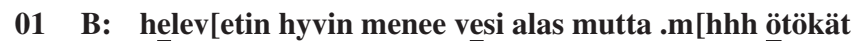
the w[ater goes down bloody well but .m [hh the bugs

02 A: [hhi hhi hhi

03 B: jostai ilmestyy että£. .mhhhhhh

[hhe hhe he

$04 \quad(0.4)$

05 B: krh-khmm Ja nyt ne on £vihaisia£. ((coughs)) and now they are £angry£.

$06 \quad(0.5)$

07 A: Mmmmm? 
$08 \quad$ (2.0) // Fr1 (1.0)

09 A: Mä en // Fr2 tiä miksei ne kuollu (.) siinä ku tota

I don't // Fr2 know why they didn't die (.) there as like

$10>$ mul oli kans< $(0.3)$ putki tukossa ja sit toi huoltomies kävi

$>$ I also had< $(0.3)$ a blocked pipe and then the service man came

11 kaatamassa si // Fr3 nne fjot(h)ain niinku klooria tai ammoniakkia to pour £som(h)ething the // Fr3 re like chloride or ammonia

12 A: tai jotain muuta vastaavaa .mhhh [hirveetä

13 B:

14 A: myrkkyä ... ((jatkaa))

poison ... ((continues $))$

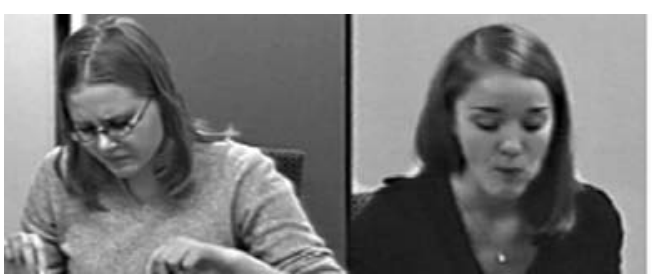

(A)
(B)

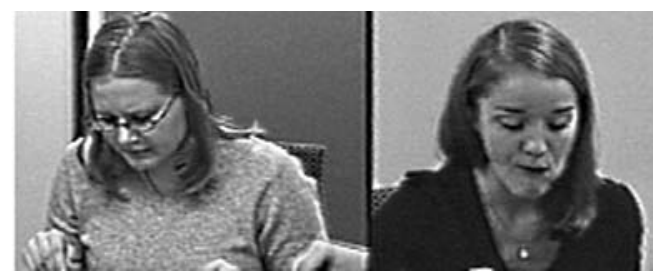

(A)

(B)

FIGURE 2 Extract 1, frames 1 and 2. (A), speaker; (B), recipient.

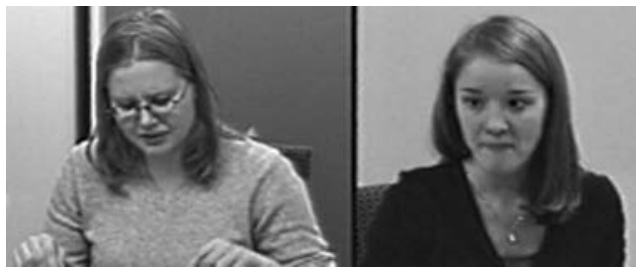

(A)

(B)

FIGURE 3 Extract 1, frame 3.

There is a $3 \mathrm{sec}$ pause prior to the onset of the second story (starting in line 9). During that silence, A frowns (frame 1). As the preceding sequence has been closed (see lines 1-7) and the participants have temporarily withdrawn from mutual engagement (note their gazes in frame 1), A's frown is associated with potentially forthcoming rather than preceding talk. The frown hints that the talk that is yet there to come will have some problematic edge in it. In retrospect this can be seen as the first index of the stance to be taken in the upcoming talk (cf. Maynard, 2003, p. 92).

One might argue that A's frown during the silence when the participants are withdrawn from mutual monitoring is not an interactional event and not associated with the talk to come. However, as it turns out, similar frowns couch A's talk to come, and a frown is eventually produced while the other participant is gazing at her. So, at the beginning of the story (and before its affective valence can be inferred from her words) A frowns again (line 9, frame 2), thus arguably expressing 
once more her stance to the talk that is to come as something problematic. But also at that point, the recipient is not gazing at the speaker. However, in line 11 (frame 3), at a point when her story's valence as one about trouble has transpired, A frowns once more, in this case when B has stopped eating and is gazing directly at her.

As will be shown in the last part of this article, this particular story has also another (humorous) valence in it. It will also be shown that the recipient acknowledges and reciprocates both stances (troubled and humorous) displayed by the speaker. In the meantime, however, what we want to point out is that in Extract 1, the speaker displayed through her face her stance toward the telling clearly before her verbal and vocal actions gave cues of that stance and even before the verbal action had started at all.

\section{FACIAL EXPRESSION ACCOMPANYING THE TELLING}

In the previous example, initial facial expression of the speaker hinted at the stance that was later on indicated also vocally. In the following Extract 2 facial expression accompanies the lexical elements of the telling and encodes the stance of the speaker to it, while the lexical elements only draw attention to the object that the recipient is invited to assess. In the extract, B is telling about a pendant that she has received as a present from somebody she has just met. The sequence in focus starts in line 5, following the closure of the previous topic ("right" in line 2) and a gap during which both participants eat, in a state of temporary disengagement. By using past tense "was" (line 5) B refers to her pendant as something they have already talked about.

Extract 2 (see Figures 4-6 for accompanying frames)

$01 \quad(4.0)$

02 B: Nä:inpä. righ:t.

$03 \quad$ (1.7) //Fr 1 ((B swallows, wipes her mouth))

04 (1.5) ((B touches her pendant, and opens her mouth to begin her announcement))

05 B: Ai niin tämmönen // Fr2 >tää oli tää < koru // Fr3 Oh yeah this is // Fr2 $>$ what this $<$ pendant was like // Fr3

06 minkä mää sain, // Fr4 that I got, // Fr4

$07 \quad(0.4)$

08 A: Nii joo. oh right.

09 B: $\operatorname{mhh}[\mathrm{e}$

10 A: [Ai se on noin iso.

$11 \quad$ (1.0) [oh it's that big.

12 A: Mä kuvittelin et se on ihan sefllanen [minif.

13 B: I thought that it's just the £kind of [mini£.

14 B: ohan >tääki nyt< (.) no, [No e:i mutta [well no: but this is $>$ also now $<$ (.) well, 
$15 \quad(0.3)$

16 A: Mmm,

$17 \quad(0.7)$

18 A: Ei mut $>$ siis mä oon< $<$ nähny sellasia ihan ni [inku vauvan no but $>$ I mean I've $<$ seen the kind just li $[\mathrm{ke}$ of the size

19 B:

[A:i jaa,

[oh: really,

20 A: £kynnen kokosia£.

£of a baby's nail£.

$21 \quad(0.3)$

22 B: No ê:i. e:i nyt sentää.

well no:. not really.

$23 \quad(0.7)$

24 B: Jo[0.

Ye $[\mathrm{ah}$.

25 A: [Joo (.) no se on tosi kaunis.

[yeah (.) well it's really beautiful.

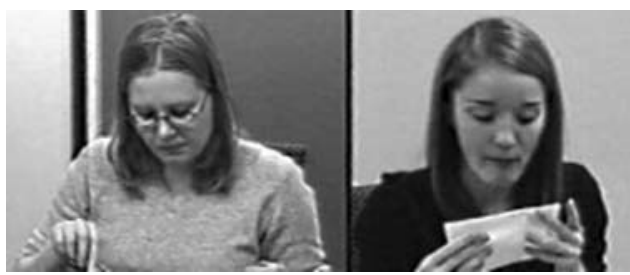

(A)

(B)

FIGURE 4 Extract 2, frame 1.

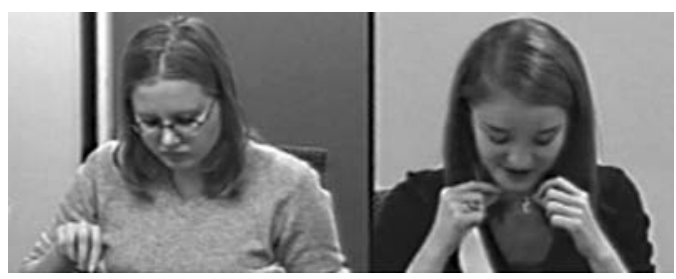

(A)

(B)

FIGURE 5 Extract 2, frame 2.

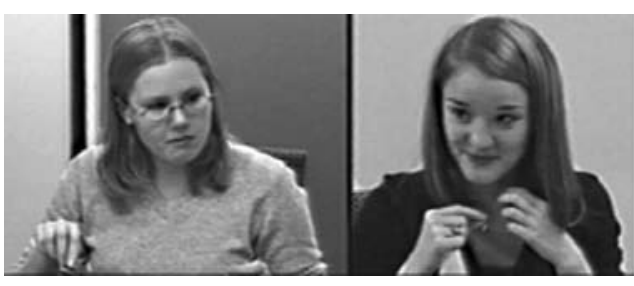

(A)

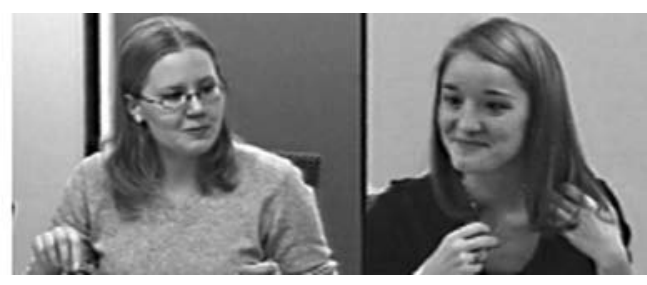

(A)
(B)

FIGURE 6 Extract 2, frames 3 and 4. 


\section{B: .hhh £Mustaki se on kyllä tosi nätti£}

.hhh $£$ I also think it's really pretty£

When making her announcement about her pendant in lines 5-6, B gazes first at her pendant (frame 2 ) and then at her coparticipant (frame 3). Around frame 3 she also gets the recipient's attention as A turns to gaze at her necklace. B's utterance: "Oh yeah, this is what this pendant was like that I got" introduces the focus of the speaker's attention, without displaying any stance toward it. However, the utterance implies that the pendant has some characteristics, or is assessable, as it refers to the quality of the pendant by the expression tämmönen, which, if standing alone, could be translated as "this kind of." The gesture (shown in frame 2) where B lifts her necklace with both hands also serves to direct the recipient's attention toward it. By thus constituting the object as assessable, without verbally assessing it, A invites an assessment from the coparticipant (cf. Fasulo \& Monzoni, 2009/this issue).

However, when showing the object and inviting an assessment, B does not leave the recipient without cues concerning the valence of the possible assessment. She starts to smile when turning her own gaze down toward the necklace and preserves her smile all through her announcement. The smile on her face gets broader toward the closure of her turn (frame 4). Her smiling facial expression, while she shows the pendant to her friend, implies the positive and appreciating stance that she herself is adopting.

Her appreciating stance gets reciprocated by A, both by her smiling facial expression and her positive lexical assessments. First, around frame 4, A starts to smile, after which she receives the announcement with "oh right" (line 8). Thereafter she further assesses the necklace saying: "oh it's that big" (line 10) and "well it's really beautiful" (line 25), thus reinforcing the positive stance of her facial assessment. Thus, B's stance toward her telling that was visible on her face (rather than in the lexical design of the turn) got reciprocated both by A's smiling facial expression as well as her appreciating lexical assessment that followed later in the conversation. In this extract, facial expression that embodied the speaker's stance accompanied the lexical elements of the telling. The latter, in turn, did not convey stance but merely introduced the assessable object.

\section{FACIAL EXPRESSION FOLLOWING THE TELLING}

In the following Extract 3, facial expression is posited at the very closure of the telling. Before the extract, the participants have been talking about A's application for a summer job at a newspaper. There has been an incipient disagreement between the two, where B has estimated A as "slightly conservative" and A has not wholeheartedly affiliated with the assessment (data not shown, but some traces of this nonaffiliation may be seen in the way in which A bites her lips in frame 1). In this context B changes the topic and tells a short story about their mutual acquaintance who had been working at a particular newspaper. (For an analysis of a more extended fragment of this particular case, see Peräkylä \& Ruusuvuori, 2006.) The punch line of the story is that this acquaintance had been ordered to wear "proper trousers" (meaning trousers with a sharp crease). This depicts the paper as very conservative and can be seen as a corrective move by B: Following the slight hitch that was caused by her evaluation of A as somewhat conservative, she starts to talk about an issue that they both can evaluate as conservative-and agree upon.

The speaker keeps a straight face almost through the whole story (lines 1-6) as shown in frame 1. However, toward the end of the punch line she first moves her gaze to the recipient (who recip- 
rocates the gaze), and then, at the beginning of the last word housut / "trousers," begins a slight smile, which she continues after the completion of her utterance. Her smile and gaze at the recipient exactly at the punch line of the story form a gestalt that is shown in frame 2.

Extract 3 (see Figures 7-9 for accompanying frames)
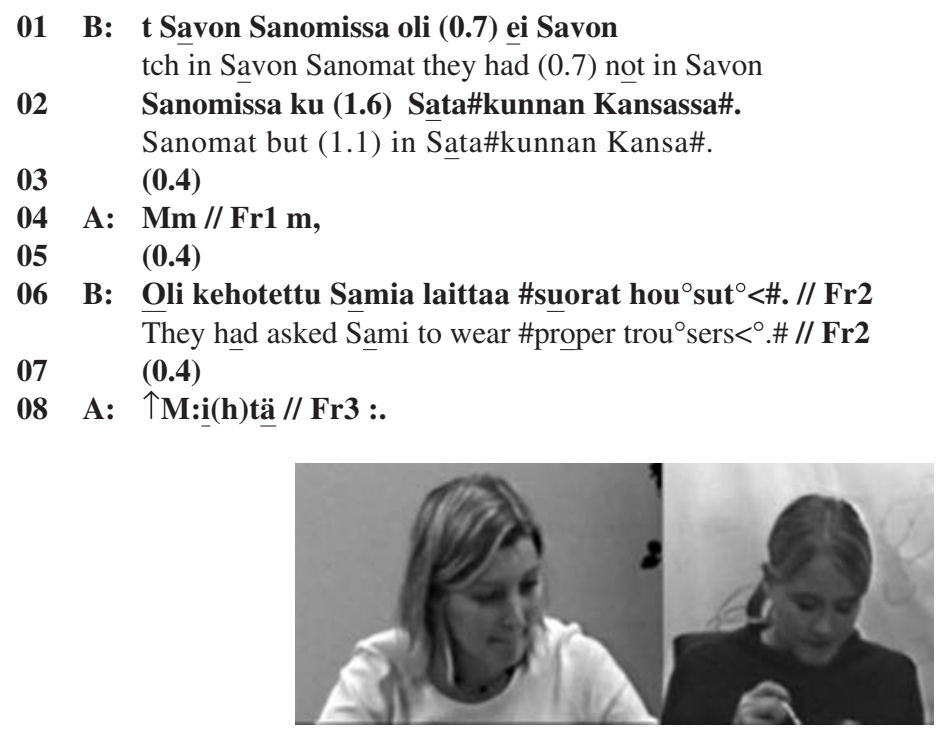

(A)

(B)

FIGURE 7 Extract 3, frame 1.

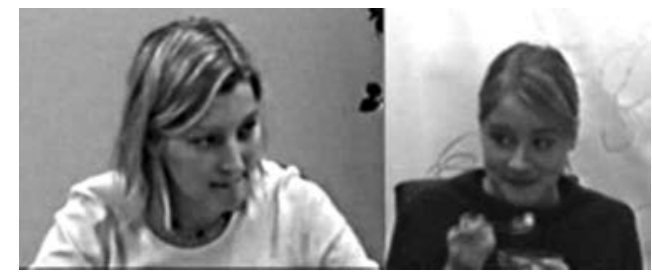

(A)

(B)

FIGURE 8 Extract 3, frame 2.

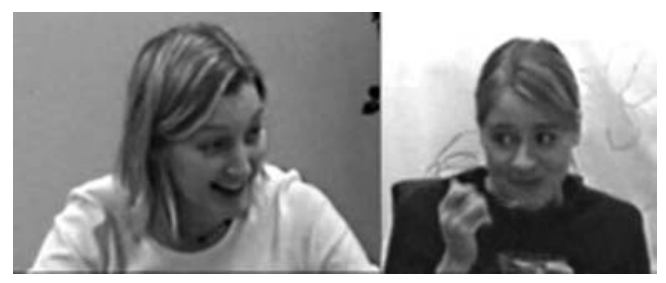

(A)

(B)

FIGURE 9 Extract 3, frame 3. 


\author{
个W:(h)ha:t // Fr3 :. \\ (0.7) \\ 10 A: Ei $\operatorname{kauh}[\operatorname{eet}(\mathbf{h}) \mathbf{a}(\mathbf{h})$. \\ No that's horr[ibl(h)e(h).] \\ [Et älä si]nne ainakaan hae $\mathbf{t}(\mathbf{h})$ olla.
}

[So don't app]ly there in any case with th(h)at one.

The telling $(1-2,6)$ is presented merely as an announcement of a past happening, and it is only the newsworthiness of the telling that implicates the potential relevance of an assessment (see Maynard, 2003, p. 95, on news-delivery sequences). There remains some freedom of interpretation of the telling: It could be heard as a complaint or a joke. B pronounces the last word of her utterance (line 6) in a cut-off manner, creating an impression of something being withheld (see Ogden, 2001) while gazing at A. Her smile brings to the open this new layer of meaning by indicating her own humorous take on the story, and at the same time, its potential laughability.

This is indeed a central aspect of how A receives the story. She reacts to the telling as (quite alerting) news through the marker of ritualized disbelief mitä / "what" (Heritage, 1984). She also starts to smile broadly, as shown in frame 3. Through her smile, the laugh particle inserted in her verbal response (line 8), as well as its high pitch (see Freese \& Maynard, 1998), A aligns as a recipient of a funny story, thus reciprocating the stance shown by B's smile at the completion of the telling.

A's response, however, is delayed: She remains silent for almost half a second after the story, and during the silence, her facial expression remains unchanged, as it is in frame 2. Through the silence, B maintains the smile on her face, thereby keeping alive her humorous take on the story, and her hint regarding its proper reception. Thus, in Extract 3, the speaker's stance toward her telling (that could have been interpreted as either a complaint or a joke) was indicated through her facial expression at the completion of this telling. The stance was eventually reciprocated by the recipient.

Facial expression that conveys the speaker's stance toward the telling can occur in different positions relative to the spoken utterance and the lexical cues regarding the stance within it. In Extract 3, the telling itself did not involve lexical or other vocal markers of stance, and the facial expression indicative of the speaker's stance occurred at the very end of the telling and lasted over the silence between the completion of the telling and the initiation of the response. Thus we get the impression that in Extract 3, the facial expression followed the lexical elements of the telling.

\section{RECIPROCATION OF STANCE SHOWN THROUGH FACIAL EXPRESSION}

The preceding three extracts showed how facial expression (embodying the speaker's stance) may appear in different locations in the production of a story or other kind of telling, thus anticipating evaluation from the recipient, and how facial expression can reinforce or create the valence of a telling. In what follows, we will show a more complex case where face serves as vehicle for conveying a twofold stance that vacillates in the course of the telling. We will provide a more detailed analysis of the storytelling initially shown in Extract 2 on the basis of a more extended segment. We will see how facial expression can be used to alert to slight shifts in the speaker's stance toward the telling. In stories where the speaker maintains a twofold stance toward the telling, the role of the face seems specifically important. 
The story in question is a second story to the recipient's (B) first story where the teller described her war against sewer bugs. In the first story B starts by an ironic comment about her having bragged about her skills in poisoning sewer bugs and yet having failed in her efforts to get rid of them. She continues by describing the situation where just following to her poisoning effort the night before, she noticed a new sewer bug in the morning. She describes her reaction to seeing the bug as angry and finishes her story with a comment about apparently having to start a new "war."

The tone of the first story is mostly humorous as the teller vividly describes her miserable failure as a bug killer, detailing her brave efforts to get rid of the bugs. However, the first conclusion of the story also has qualities of a troubles-telling, indicating that the problem still exists. After this story, the participants for a while talk about sewer bugs and reasons for their invasion. Just preceding the second story, the teller of the first story (B) returns for a moment to the storytelling, reclosing her story with a description of a remaining problem: "the water goes down bloody well but the bugs appear from somewhere" and a humorous closing remark: "And now they are angry" (see Extract 1). The second story by A starts at line 9 in Extract 4.

In terms of its lexical design, the second story carries a twofold stance toward the events described: troublesome and humorous. The beginning ("I don't know why they didn't die"), as well as the punch line ("those bugs didn't seem to give a hoot") implicate a troubles-telling: The teller has a problem as the bugs have not died. This orientation to a problem is embedded also in the negative observation made in the beginning ("they didn't die") (Halonen, 2005). The humorous stance is implicated by the exaggerations in the way in which the teller describes the procedures engaged in by the janitor ("then the service-man came to pour something there like chloride or ammonia or some other terrible poison that smoked and the whole toilet smelled real bad for many days afterwards"), as well as in the playful way that the end result was described ("didn't give a hoot").

The vacillating stance is also expressed by face. As we already saw in Extract 1, A's frowning just preceding the beginning of her second story in line 8 (frame 1 in Extract 1) marks a problematic aspect of her telling. This problematic aspect is reinforced again by frowns in lines 9 (frame 2 in Extract 1) and 11 (frame 3 in Extract 4). Later, when turning to gaze at B, A, however, smiles (see frame 5 in Extract 4). Her smile begins at the point preceding the punch line or the result of the story (lines 11-12, frames 4 and 5 below), where she uses exaggerating words to describe the procedures that the janitor took in order to get rid of the bugs in her sewer.

Extract 4 (see Figures 10-14 for accompanying frames)

01 B: helev[etin hyvin menee vesi alas mutta .m [hhh ötökät the w [ater goes down bloody well but .m [hhh the bugs

02 A: [hhi hhi hhi [hhe hhe he

03 B: jostai ilmestyy ettäf. .mhhhhhh appear from somewheref .mhhhhhh

$04 \quad(0.4)$

05 B: krh-khmm Ja nyt ne on £vihaisia£. ((coughs)) and now they are £angry£.

$06 \quad(0.5)$

07 A: Mmmmm?

$08 \quad$ (3.0)

09 A: Mä en tiä miksei ne kuollu (.) siinä ku tota I don't know why they didn't die (.) there as like 
$10>$ mul oli kans< (0.3) putki tukossa ja sit toi huoltomies kävi $>$ I also had $<(0.3)$ a blocked pipe and then the service man came

11 kaatamassa si // Fr3 nne £jot(h)ain niinku klooria // Fr4 pour there something like chloride to pour £som(h)ething the // Fr3 re like chloride // Fr4 or ammonia // Fr5

13 tai jotain muuta vastaavaa mhhh [hirveetä

14 B: or some other equivalent .mhh [terrible

15 A: myrkkyä mistä nous savua ja .hhh ja tota (.) koko vessa poison that smoked and .hhh and erm (.) the whole toilet
[A turns to gaze down
(A smiles)

16 hais£ [(0.6) tosi pahalle mon[ta päivää sen jä // Fr6 lkeen, $={ }^{\circ}$ mut $^{\circ}$ smelled $\left[(0.6)\right.$ real bad for man[y days aft // Fr6 erwards, $={ }^{\circ}$ but ${ }^{\circ}$

17 B: $[B$ glances at $A$

[Mmm.

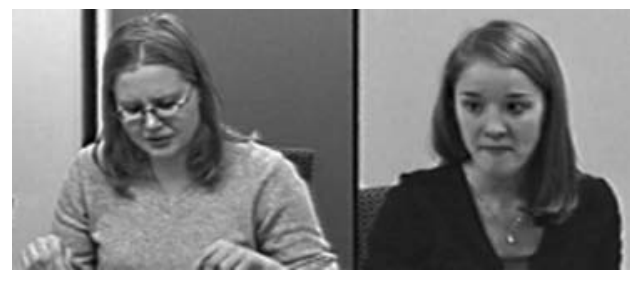

(A)

(B)

FIGURE 10 Extract 4, frame 3.

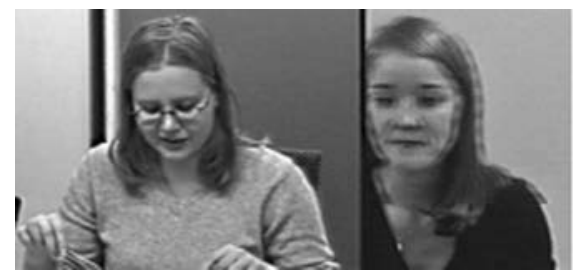

(A)

(B)

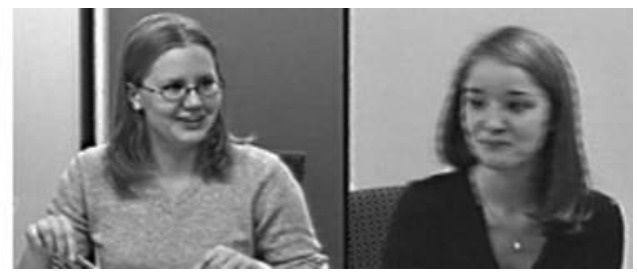

(A)

(B)

FIGURE 11 Extract 4, frames 4 and 5.

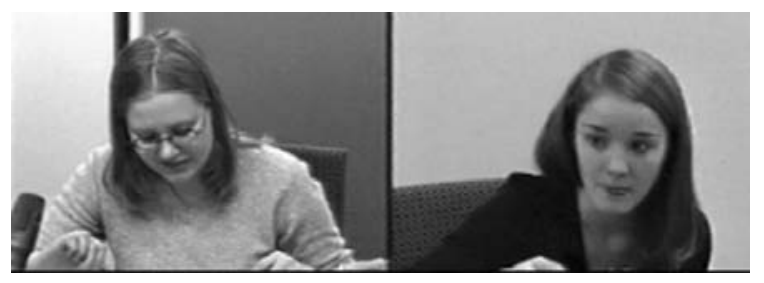

(A)

(B)

FIGURE 12 Extract 4, frame 6. 


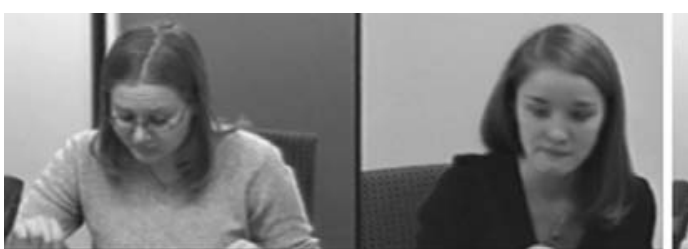

(A)
(B)

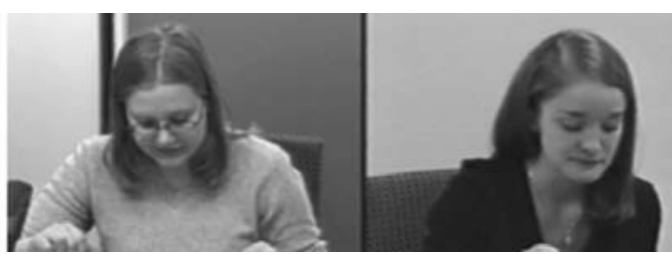

(A)

(B)

FIGURE 13 Extract 4, frames 7 and 8.

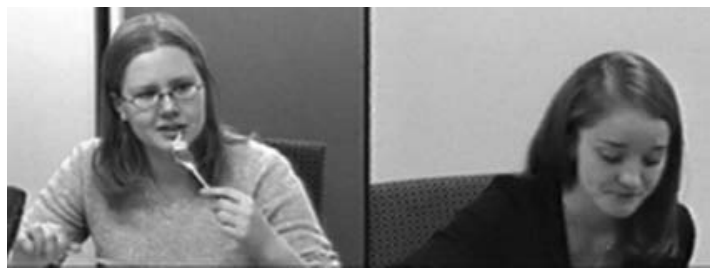

(A)

(B)

FIGURE 14 Extract 4, frame 9.

18

19

\section{(0.5) // Fr 7-8 (A frowns and shakes her head)}

\section{[A turns to gaze at B}

\section{A: Ei ne ötökät siitä (0.3) ollu moksis // Fr9 [kaa.}

Those bugs didn't (0.3) give a hoot // Fr9 [about it.

As we saw, A started smiling at line 11 at frame 4. Her smile continues also when she turns her gaze down toward her food at line 16, all the way until she starts the punch line "those bugs didn't give a hoot about it" (line 19). Her smile stops at the word "but" (end of line 16, frame 6). At the gap in line 18, she frowns and shakes her head (frames 7 and 8), this way repeating, through her face and gesture, in short both the stances she has implied in her story.

During A's story the recipient (B) shows in various ways that she is attending to the story. In line 13 she utters a nii response that marks a place of maximum incompleteness in the story (Sorjonen, 2001, pp. 232-238). She gazes at A most of the time, starting at line 9 when A says the word "die," until line 15 where A stops for a moment and takes a preturn inbreath. Here B also nods slightly while turning to gaze down. After this point, B mostly looks down eating her lunch, but glances at A at line 16 when A says "many days afterwards."

At the end of line 19 while pronouncing the last word of her story, A turns to gaze at B (frame 9), this way marking that she is ready to pass the turn to her recipient (C. Goodwin, 1979; see also Lerner, 2003). At this point, A's face is rather neutral, with just a hint of a smile.

Next, we will focus on B's way of receiving A's second story. The evaluation is slightly delayed and at first it lacks explicit assessment by B. Extract 5 is a direct continuation of Extract 4 .

Extract 5 (see Figures 15-18 for accompanying frames)

19

(1.0)

20 B: Hmh, 
$21 \quad(2.3) / /$ Fr10

22 A: Luulis > et se ois< tappanu isommanki eläimen. // Fr11 You'd have thought $>$ that it had $<$ killed even a bigger creature.//Fr11

23 (0.7) ((B tilts her head))

24 A: Sellanen satsi [mitä se sinne laitto.

25 B: the sort of load [that he poured there.

[Nii-i.

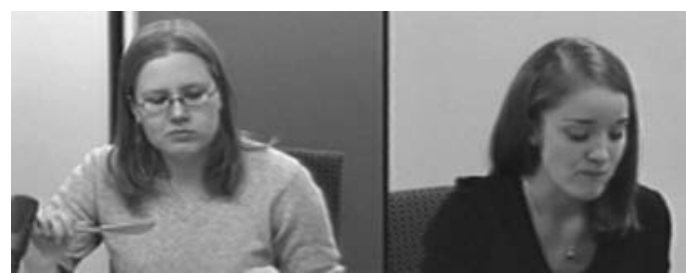

(A)
(B)

FIGURE 15 Extract 5, frame 10.

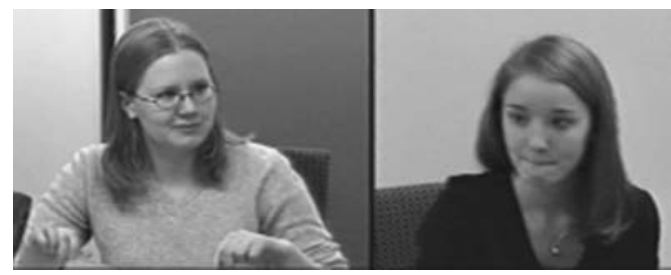

(A)

(B)

FIGURE 16 Extract 5, frame 11.

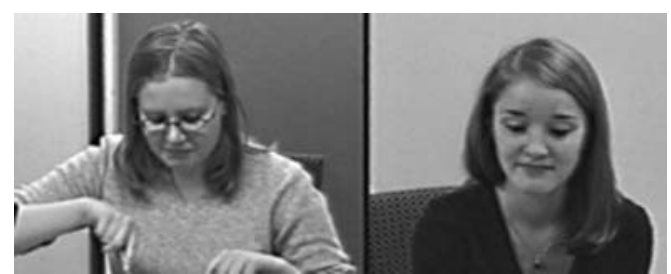

(A)

(B)
FIGURE 17 Extract 5, frame 12.

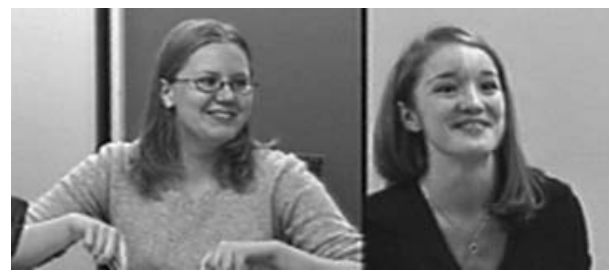

(A)

(B)

FIGURE 18 Extract 5, frame 13. 
[Yeah.

$26 \quad(1.3)$

27 B: $£$ mhh .mhh£ // Fr12 [(0.5) £Koht(h)a (h)jok [u sairastunu

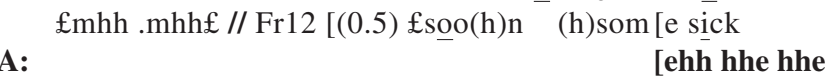

28 A:

29 B: karhunpoika [(h)juoksee sieltä helvetti£ // Fr13, hhe he .mhhh

30 A:

bear-puppy'll [(h)emerge from there damn it£ // Fr13, hhe he .mhhhh

Unlike what one perhaps might expect, B's facial expression doesn't change directly in response to the storyteller's facial expression. Even when the teller starts to smile and they have gaze contact, the smile is not clearly reciprocated by B while the story is ongoing (frame 5). Thus, it seems that A's smiling facial expression as such is not enough to invite a smile from her recipient. At the closure of the story, A's smile also remains unreciprocated (frame 9) as B keeps gazing at her food while eating her lunch. In the continuation of Extract 5, we see how, after a $1.0 \mathrm{sec}$ gap, the recipient, however, acknowledges the troublesome aspect: She utters "hmh" and shakes her head (frame 10). Although at this point an evaluation of the story would be relevant (Sacks, 1974; Jefferson, 1978), B does not start an assessment sequence here.

Lacking relevant response (story-evaluation) from B, A continues her story in line 22 with an assessment that refers to the proposed powerful effect of the poison spread by the janitor "you'd have thought that it would have killed even a bigger creature." She qualifies the assessment with a smile at the end of her turn (frame 11). B responds by tilting her head slightly (line 23) but not reacting otherwise, and A adds an increment to her utterance: "the sort of load that he poured in there." Overlapping with the increment, B receives A's evaluation with the dialogue particle nii (line 25) that in this context claims affiliation with A's evaluation. A single nii as a response to an assessment is not a very strong affiliation in Finnish, and it can suggest a closure of the activity (Sorjonen, 2001, p. 193-195). So far these features all together suggest that B's response to A's story is less than enthusiastic.

There follows a gap of $1.3 \mathrm{sec}$ (line 26) after which B eventually snorts, starts smiling and jokingly describes potential consequences of A's story, which marks a stronger affiliation with the preceding assessment than a plain nii does (see Ruusuvuori, 2005). Following B's snort, A also starts smiling (frame 12). With her smiling and joking B both acknowledges the humorous side of A's story and displays that she has understood the point of it. Her proposition of affiliation gets accepted by A, who starts laughing while B is uttering her humorous evaluation in a smiley voice (line 28). The story closes at their mutual laughter and reciprocated smiles (frame 13).

The observations made in the storytelling analyzed on the basis of Extract 5 can be summed up as follows:

1. Facial expression displayed the speaker's vacillating stance, corresponding to the vocal action where the twofold stance was also observable. Face was used (alongside the lexical cues) to alert the recipient to slight changes of stance toward the telling during its course. Both stances were eventually reciprocated by the recipient.

2. When at first only one stance (story about trouble) was acknowledged by the recipient, and the recipient's evaluation was missing, facial expression that signified the other (humorous) stance was repeated by the speaker while she herself made the first evaluation of her story. This, with the smiling response and joking evaluation that she 
eventually got, implies that face works (together with the lexical cues) as a way to pursue appropriate response to the teller's stance toward the story (see Pomerantz, 1984; cf. Mondada, 2009/this issue).

3. Although it is known that facial expressions are not always reciprocated, in this particular case both of the stances that were displayed by face were actually reciprocated nonlexically, i.e., the negative stance was reciprocated with a headshake and a negatively toned acknowledgement "hmh," and the humorous stance with smile and laughter.

4. The storyteller accepted the recipient's response to her story as adequate only after both implied stances were adequately reciprocated.

\section{CONCLUSION}

The conclusion of our analysis is that facial expression contributes to the interactional production of assessments in conversation. We have shown some aspects of this interactional work of the face, and indicated some ways that it can be scrutinized.

Charles Goodwin $(2000 ; 2007)$ has pointed out that the human body can be seen as a dynamically unfolding, interactively organized locus of production of meaning and action. We have here examined the interplay of two modalities of meaning production, the spoken language and the facial expression in a specific sequential context, in creating a shared understanding of the meaning of a story or an announcement. We have seen a few examples of the ways in which face works as a resource in the collaborative generation of assessment sequences after storytelling or at the closure of other kinds of tellings. In all extracts that were shown, facial expression worked alongside the lexical cues in giving hints of the speaker's stance toward her telling, and in assuring appropriate response. In all cases the stance that was implied in the facial expression of the speaker was eventually also reciprocated by the recipients.

Drawing upon our analysis, facial expression is a flexible interactional resource that is easily adaptable to the contingencies of a situation. This was observable for instance in Extract 3, where the recipient's reaction to the story told was delayed, implying a potential misalignment. In this situation the speaker smiled at the very end of her story and remained smiling after it, thus proposing the interpretation of her story as funny and keeping this proposal alive through the silence following the story, shunning other possible interpretations and in this way preempting disaffiliation. Another example of this was offered in Extracts 4 and 5 where the storyteller conveyed a vacillating stance toward her second story, with the help of her rapidly changing facial expression.

Our analyses lend support to Marjorie Harness Goodwin's ideas (1980) about the important role of kinesic displays for the organization of interaction in the context of assessment. Face is a resource both for the speaker and for the recipient, and it serves in the construction of meaning as well as in shaping the relationship between the participants.

In our earlier work (Peräkylä \& Ruusuvuori, 2006) we suggested that the temporal organization of facial expression is related to, but not completely identical with, that of the spoken utterances. It appeared to us that facial expression, as it were, stretches the boundaries of the turns at talk (cf. Mondada, 2006). The cases presented in this article lend further support to that hypothesis. In Extract 3, the smile of one participant begins toward the end of her utterance, and that smile continues over the silence that follows the utterance. The intention and state of mind that was in- 
corporated in the spoken utterance remains there, incorporated in the face, even when the utterance has been completed. In Extract 1, we saw a case where the facial expression preceded an utterance which, as it turned out, conveyed the same affective state that the preceding facial expression initially incorporated. So, in an intriguing way, the face seems to be able to stretch the temporal boundaries of an action: to make some aspect of it begin before the turn at talk that conveys it begins, and to make some aspect of it persist after the turn at talk that has conveyed it has been completed. We might suggest that this temporal flexibility of the face also enforces the role of face as one subtle and easily deployable device in securing shared understanding and affiliation. In Extract 3 the smiling facial expression of the storyteller occurs in a conversational context where an affiliating response in the form of an assessment to the telling is due. It seems possible that the smiling facial expression here works in the similar way as would a lexical first assessment by the teller that would be given when lacking an appropriate affiliation from the recipient. In Extract 3 where the speaker did not clearly show her stance toward her spoken utterance and the response was delayed, through her facial expression she was able to quickly and unobtrusively hint at an appropriate way to receive her announcement, thus avoiding a more overt, vocal clarification of meaning (Schegloff, Jefferson, \& Sacks, 1976).

In theoretical and methodological terms, our approach to facial expression was particularly inspired by the earlier work of Bavelas and Chovil (Bavelas \& Chovil, 1997; 2000; Chovil, 1991; 1997). From them, we received the key idea of studying face as a communicative resource rather than as channel of expression of internal states. However, conversation analytic ideas regarding the momentary interactional unfolding of action helped us, we believe, to take the analysis yet another step further (see Peräkylä \& Ruusuvuori, 2006). While it appears that Bavelas and Chovil contextualize facial expressions in complete linguistic actions such as asking questions or giving a personal reaction to what is spoken (see Chovil, 1991), our conversation analytic approach helped us to clarify the role of facial expressions in the step-by-step unfolding of one particular action, assessment.

\section{REFERENCES}

Bavelas, J., \& Chovil, N. (1997). Faces in dialogue. In J. A. Russell \& J.-M. Fernández-Dols (Eds.), The psychology offacial expression (pp. 334-346). Cambridge, UK: Cambridge University Press.

Bavelas, J., \& Chovil, N. (2000). Visible acts of meaning: An integrated message model of language in face-to-face dialogue. Journal of Language and Social Psychology, 19, 163-194.

Chovil, N. (1991). Discourse-oriented facial displays in conversation. Research on Language and Social Interaction, 25, 163-194.

Chovil, N. (1997). Facing others: A social communicative perspective on facial displays. In J. A. Russell \& J.-M. Fernández-Dols (Eds.), The psychology offacial expression (pp. 321-333). Cambridge, UK: Cambridge University Press.

Ekman, P. (1979). About brows: Emotional and conversational signals. In M. von Cranach, K. Foppa, W. Lepenies, \& D. Ploog (Eds.), Human ethology (pp. 169-202). Cambridge, UK: Cambridge University Press.

Ekman, P. (2003). Emotions revealed. New York: Henry Holt.

Ekman, P., Sorenson, E. R., \& Friessen, W. V. (1969). Pan-cultural elements in facial displays of emotion. Science, 164, 86-88.

Fasulo, A., \& Monzoni, C. (2009/this issue). Assessing mutable objects: A multimodal analysis. Research on Language and Social Interaction, 42, 362-376.

Freese, J., \& Maynard, D. W. (1998). Prosodic features of good news and bad news in conversation. Language in Society, 27, 195-219.

Fridlund, A. (1996). "Facial expressions of emotion" and the delusion of the hermetic self. In R. Harré \& W. G. Parrott (Eds.), The emotions: Social, cultural and biological dimensions (pp. 259-284). London: Sage. 
Goodwin, C. (1979). The interactive construction of a sentence in natural conversation. In G. Psathas (Ed.), Everyday language: Studies in ethnomethodology (pp. 97-121). New York: Irvington Publishers.

Goodwin, C. (2000). Action and embodiment within situated human interaction. Journal of Pragmatics, 32, $1489-1522$.

Goodwin, C. (2007). Participation, stance and affect in the organization of activities. Discourse \& Society, 18, 53-73.

Goodwin, C., \& Goodwin, M. H. (1987). Concurrent operations on talk: Notes on the interactive organization of assessments. Pragmatics, $1,1-54$.

Goodwin, C., \& Goodwin, M. H. (1992). Assessments and the construction of context. In C. Goodwin \& A. Duranti (Eds.), Rethinking context: Language as an interactive phenomenon (pp.147-189). Cambridge, UK: Cambridge University Press.

Goodwin, C., \& Goodwin, M. H. (2000). Emotion within situated activity. In A. Duranti (Ed.), Linguistic anthropology: A reader (pp. 239-257). Malden, MA: Blackwell.

Goodwin, M. H. (1980). Processes of mutual monitoring implicated in the production of description sequences. Sociological Inquiry, 50, 303-317.

Halonen, M. (2005). Mä en sit siihe sanonu mitää—Raportit sanomatta jättämisestä ja evidentiaalinen partikkeli sit(te(n)) keskustelun kertomuksissa [Reports on not having said something and evidential particle sit(te(n)) in stories in conversations]. Virittäjä, 109, 272-298.

Heath, C. (1986). Body movement and speech in medical interaction. Cambridge, UK: Cambridge University Press.

Heritage, J. (1984). A change-of-state token and aspects of its sequential placement. In J. M. Atkinson \& J. Heritage (Eds.), Structures of social action: Studies in conversation analysis (pp. 299-345). Cambridge, UK: Cambridge University Press.

Izard, C. (1971). The face of emotion. New York: Appleton-Century-Crofts.

Jefferson, G. (1978). Sequential aspects of storytelling in conversation. In J. Schenkein (Ed.), Studies in the organization of conversational interaction (pp. 219-248). New York: Academic Press.

Kjaerbeck, S., \& Assmuss, B. (2005). Negotiating meaning in narratives. Narrative Inquiry 15, 1-24.

Lerner, G. (2003). Selecting next speaker: The context-sensitive operation of a context free organization. Language in Society, 32, 177-201.

Maynard, D. (2003). Bad news, good news: Conversational order in everyday talk and clinical settings. Chicago: The University of Chicago Press.

Mondada, L. (2006). Participants' online analysis and multimodal practices: Projecting the end of the turn and the closing of the sequence. Discourse Studies, 8, 117-129.

Mondada, L. (2009/this issue). The embodied and negotiated production of assessments in instructed actions. Research on Language and Social Interaction, 42, 329-361.

Ochs, E., \& Capps, L. (2001). Living narrative: Creating lives in everyday storytelling. Cambridge, MA: Harvard University Press.

Ogden, R. (2001). Turn transition, creak, and glottal stop in Finnish talk-in-interaction. Journal of International Phonetics Association, 31, 139-152.

Peräkylä, A., \& Ruusuvuori, J. (2006). Facial expression in an assessment. In H. Knoblauch, B. Schnettler, J. Raab, \& H-G. Soeffner (Eds.), Video analysis: Methodology and methods (pp. 127-142). Frankfurt am Main, Germany: Peter Lang.

Pomerantz, A. (1984). Pursuing a response. In J. M. Atkinson \& J. Heritage (Eds.), Structures of social action (pp. 152-163). Cambridge, UK: Cambridge University Press.

Ruusuvuori, J. (2005). "Empathy" and "sympathy" in action: Attending to patients' troubles in Finnish homeopathic and general practice consultations. Social Psychology Quarterly, 68, 204-222.

Sacks, H. (1974). An analysis of the course of a joke's telling in conversation. In R. Bauman \& J. Sherzer (Eds.), Explorations in the ethnography of speaking (pp. 337-353). Cambridge, UK: Cambridge University Press.

Schegloff, E. A. (1997). "Narrative analysis" thirty years after. Journal of Narrative and Life History, 7(1-4), 97-106.

Schegloff, E. A., Jefferson, G., \& Sacks, H. (1976). The preference for self-correction in the organization of repair in conversation. Language, 53, 361-382.

Sorjonen, M.-L. (2001). Responding in conversation: A study of response particles in Finnish. Amsterdam: John Benjamins.

Stivers, T. (2008). Stance, alignment and affiliation during story telling: Nodding as a token of preliminary affiliation. Research on Language \& Social Interaction, 41, 31-57. 